\title{
REPUTATION AND THE PALMER RULE IN THE ORIGINS OF BANKING IN SPAIN
}

YOLANDA BLASCO-MARTEL

Universitat de Barcelona $^{\mathrm{a}}$

\begin{abstract}
This paper investigates the reasons why provincial issuing banks in Spain maintained high reserves in the $19^{\text {th }}$ century and the effects this had. The introduction of banknotes into the economy meant that convertibility had to be guaranteed. If convertibility was respected, this gave banks a good reputation and made them reliable. The Palmer Rule was a control mechanism stating that a well-managed bank should keep one-third of its liabilities as cash in hand and two-thirds in securities. In Spain the banking system, constituted in the mid- $19^{\text {th }}$ century, was characterised by a plurality of issuing banks. Regulations required reserves only to secure notes, with no mention of reserve requirements for banks' other types of liabilities. However, Spanish provincial banks of issue adopted the Palmer Rule. The Bank of Spain did not follow the same path.
\end{abstract}

Keywords: Palmer rule, banking reputation, convertibility, Spain

JEL Code: N24, E58 y G18

\section{RESUMEN}

Este trabajo investiga las razones y los efectos que tuvo el que los bancos de emisión provinciales en España mantuvieran elevadas reservas en el siglo XIX. La inserción de los billetes de banco en la economía requirió garantizar la convertibilidad. Si se respetaba la convertibilidad, esto daba a los bancos buena reputación y los hacía confiables. La Palmer Rule era una norma de control que establecía que un banco bien administrado debería mantener en

a Departament d'Història Econòmica, Institucions, Política i Economia. yolandablasco@ub.edu 
su caja en metálico un tercio de sus responsabilidades. En España el sistema bancario se conformó a mediados del siglo XIX en base a un sistema plural de emisión, sin competencia entre los diferentes billetes circulantes. La regulación requería reservas para garantizar los billetes, sin contemplar garantía alguna para el resto de pasivos bancarios. Pero los bancos emisores provinciales adoptaron la Palmer Rule; no sucedió lo mismo con la senda seguida por el Banco de España.

Palabras clave: Regla de Palmer, reputación bancaria, convertibilidad, España

\section{INTRODUCTION}

The introduction of paper money as a monetary instrument was a long process that took place throughout the $19^{\text {th }}$ century and was consolidated in the early $20^{\text {th }}$ century. The banknote was the main innovation of this period and its role in the economy was closely linked to the development of banks of issue. The convertibility of notes into metal was a legal requirement that enabled this innovation to spread. The convertibility guarantee of a new type of currency was clearly linked to the reputation of the issuer and the regulatory framework that allowed it to circulate. The objective of this article is to analyse the causes and the effects of Spain's metallic reserve-holding requirements and practices on the acceptance of banknotes and the expansion of deposits - that is to say, on the development of an economy based on non-metallic money.

The importance of reputation in business, to alleviate problems of asymmetric information and the lack of legal and contract enforcement, is especially decisive in the banking sector. Current analyses emphasise that "the reliability and financial strength dimension is present in most general and specific models, and it makes reference to the abilities that firms have to generate benefits in order (...) to guarantee customers' deposits in the case of banks» (Ruiz et al. 2014, p. 264). This financial strength is an identifiable key factor in banking reputation in times of crisis. Recent works support the relevance of financial reputation to determine bank access to debt markets (Camba-Mendez et al. 2014). Diamond's analysis of reputation formation in the credit markets (Diamond 1983) established that the monitoring of firms was the initial stage through which one passes to obtain a good reputation when the moral hazard is widespread. From a historical perspective, the works of Gorton (1996) and Knodell (2010) are concerned with linking the available information about the initial banknotes in the United States, and the appearance of monitoring mechanisms that made them credible. Specifically, Gorton, following Diamond, points out that «redemptions serve the 
purpose of monitoring the new Banks» (Gorton 1996, p. 361). In the early banking experiences of the $19^{\text {th }}$ century, a factor linked to the reputation of a banking institution was its solvency. Some bank managers emphasised the strength of their cash as a measure of the strength of their balance sheet. This strength would guarantee, in case of a crisis, the bank's capacity to redeem its notes. The issue banks of the mid- $19^{\text {th }}$ century provided disaggregated information on their balance sheets in order to inform agents and, possibly, to guide them on the control of the bank's management (Bernal Lloréns and Sánchez Ballesta 2008).

More recent works explore the role of reputation as a substitute mechanism against the weakness or inefficiency of state regulation (Allen et al. 2005). In Spain, the Bank of Spain originated as a bank linked to the state's needs, the Bank of San Carlos, which appeared at the end of the $18^{\text {th }}$ century. In the central decades of $19^{\text {th }}$ century, twenty provincial issuing banks appeared linked to industry and commerce. The multiplicity of banks of issue until 1874, when the Bank of Spain monopolised the issue of money, allowed notes to be found throughout the country. The banking regulation that gave birth to these banks was inspired by European rules (especially British and French). In addition to official regulation, the provincial banks introduced a rule which was known among European banks. This rule was inspired by the Palmer Rule, which owes its name to John Horsley Palmer, Governor of the Bank of England between 1830 and 1833. The follow-up to this rule involved «to invest and retain in securities, bearing interest, a given proportion of the deposits, and the value received for the notes in circulation, the remainder being held in coin and bullion; the proportions which seem to be desirable, under existing circumstances, may be stated at about two-thirds in securities and one-third in bullion» ${ }^{1}$. That is, Palmer's rule required keeping one-third of the bank's liabilities (notes and deposits) in cash. This rule has the peculiarity that it had been assumed by the banking system in general but was not formally part of the banking regulation of the time. J. H. Palmer acknowledged that experience was behind the adoption of this reserve rule in the Bank of England.

The importance of the adoption of the Palmer Rule, in a period of extension of a new type of currency, is related to the need to establish trust in paper money. The Bank of England's experience over more than a century was not comparable to that of the banks that emerged between the late $18^{\text {th }}$ and mid- $19^{\text {th }}$ centuries throughout the world. Some of these early banks, although private, were born linked to the needs of the states, which somehow sustained them in times of difficulty. However, the new issuing and commercial banks had to rely on the reputation of their directors and operations to offer guarantees to their clients on the reliability of their notes (their ability to be redeemed at sight).

\footnotetext{
${ }^{1}$ Report from the Committee of Secrecy on the Bank of England Charter, 1932, pp. 7-70.
} 
The origins of banks' convertibility rules (formal and informal) are to be found in the episodes of suspension of convertibility experienced in England from 1797 until 1821, when the «full redemption of specie payments» (Fetter 1965, p. 96) was adopted again. England had de facto adopted the gold standard at the end of the $17^{\text {th }}$ century (in 1816 the demonetisation of silver occurred, although it is not possible to identify a definite gold standard until the regulation of 1821; Fetter 1965, p. 64), while most other countries maintained a bimetallic system (Flandreau 1995, pp. 25-26). From the 1870s most European countries adopted the gold standard. Spain, however, was not among them ${ }^{2}$. The starting point of this article is an analysis of the norms of convertibility adopted by the incipient Spanish banking system during the so-called period of «plurality of emission». This plurality is not the same as free banking, since free banking grants the freedom to create banks and the non-existence of privileges; this was not the case in Spain.

This paper examines the introduction of the Palmer Rule into Spanish banking legislation and the degree to which Spanish banks of issue respected this rule. The article covers the period from the creation of the Bank of San Fernando (later re-named The Bank of Spain) in 1829, until the law of 1921 which initiated the process by which the Bank of Spain became the Central Bank. Initially, deposits played a relatively insignificant role in provincial banks' passive liabilities, while current accounts played a larger role. The latter were regarded as a service provided by institutions to enable customers to collect or make payments, and for which they paid a fee ${ }^{3}$. Until the promulgation of the 1885 Commercial Code, Spanish banking regulations obviated the reserve requirements of deposits and current accounts and demanded only that banks guarantee notes in circulation. However, while provincial banks incorporated reserve requirements for the convertibility of all instruments, the bank associated with the state did not. This means that early provincial banks applied the Palmer Rule, guaranteeing their liabilities, while the Bank of Spain constantly broke this rule.

Was the application of the Palmer Rule by the issuing banks a Spanish peculiarity? International literature considers that this rule was linked to the banks that worked with their governments. In Spain this had a particular application: regulation did not reflect the reserve requirements necessary to cover sight deposits, however the provincial banks followed the requirement

\footnotetext{
${ }^{2}$ A recent working paper by Martínez-Ruíz and Nogués-Marco (2018) points out the responsibility of the Bank of Spain to defend gold adherence.

3 This is a key aspect, for at least legally, these funds could not be loaned out initially. The royal decree that in 1829 acknowledged the creation of the Spanish Bank of San Fernando stated that current accounts paid the bank for its services (art. 28). Blasco-Martel and Sudrià (2010, p. 97) explain that, initially, the Bank of Barcelona charged for cheque books. Officially, voluntary deposits were not remunerated, and indeed, they initially carried a fee. Pastor Rodríguez pointed out in the mid-1800s that «the few Banks that have existed and exist have paid no interest on the amounts that they have received from current accounts» $(1850$, p. 22).
} 
of keeping in cash a third of both notes and deposits. The Bank of Spain did not. The explanation for this behaviour can be found in that the Bank of Spain, despite being a private bank, maintained a strong link with the state. This link was certainly contradictory because it was a private bank that had to respond to the interests of its shareholders but, at the same time, it had a commitment to the Treasury. Pablo Martin Aceña rightly defines this relationship: «The Treasury needed a financial agent for its own survival», but simultaneously, «it was the State's financial needs that helped to keep the institution (Bank of Spain) alive» (Martín-Aceña 2017, p. 21). The relationship between the state and the Bank of Spain was one of mutual dependency. The Bank of Spain understood that its obligations were to finance the government and act as issuer of banknotes, and it tried to maintain its autonomy throughout the period. It did not feel involved with financing the economy and, in fact, «It was a kind of (financial) State within the State» (Martín-Aceña 2017, p. 32). On the other hand, the provincial banks, which had the exclusive privilege of issuing paper money in their territories, maintained a proximity to the local business world and had to build their reputation in order to circulate their banknotes. Undoubtedly, the way in which banknotes were introduced had much to do with its subsequent extension to the whole country, when in the 1880s the Bank of Spain issued just one note for the whole country.

The first part of this article describes the relationship established in England between notes and deposits briefly, and the application of the Palmer Rule in that country. It then turns to look at the regulations established by Spain's banks of issue regarding the emission of notes. We then analyse the application of the Palmer Rule by banks of issue, as well as the Bank of Spain's inability and/or unwillingness to apply it. Finally, we examine the regulation of notes and convertibility until the Act of 1921. A brief conclusion closes the article.

\section{BANKNOTES, DEPOSITS AND THE PALMER RULE}

The incorporation of banknotes into the English economy generated a debate between those who favoured this new financial instrument, and those who opposed it; the debate centred on the characteristics, functions and effects of notes, and addressed their monetary or credit character. At the end of the $18^{\text {th }}$ and the beginning of the $19^{\text {th }}$ centuries, Adam Smith's ideas on banknotes as representing gold and silver in a country's internal operations, and their relationship with negotiable instruments, were commonly accepted. However, some ambiguities surrounding the concept of real bills set forth by this Scottish philosopher had generated discrepancies ${ }^{4}$. The real

${ }^{4}$ On the ambiguities and paternity of the real bills doctrine, see Perlman (1989), who argues that Adam Smith did not develop the real bills doctrine, which in fact contradicts his propositions, 
bills doctrine held that the expansion of the monetary supply should only take place in response to the necessities of commerce (Humphrey 1982, pp. 3-4). Henry Thornton believed that banknotes substituted bills of exchange rather than bullion, and that they were similarly based on trust ${ }^{5}$. This discussion formed the very origin of the division between bullionists (who essentially upheld the ideas proposed by the quantitative theory of money, and declared themselves supporters of a convertible metallic standard, thus anchoring the monetary supply to bullion) and anti-bullionists (who appealed to the real bills doctrine and argued that the emission of paper money should be linked to the demand for credit). Eventually, these two positions led to the development of two separate monetary doctrines, ongoing throughout the $19^{\text {th }}$ century: the Currency School and the Banking School. Both intellectual currents argued about the regulation and control of monetary instruments, defending positions that were crystallised in England in the 1844 Peel Banking Act (Poitras 1998, p. 379). If in 1844 the Currency School triumphed, by the end of the $19^{\text {th }}$ century, the Banking School had won more followers.

The use of banknotes was widespread in England thanks to the combination of a dynamic credit market and the proliferation of financial intermediaries. The economic surplus produced by agriculture generated deposits that were used to finance industry and commerce. These activities required a diverse set of agents: brokers, country banks, and the London City bankers and banks, including the Bank of England. Rural savings were thus invested in profitable projects that provided liquidity to industry and commerce, and savers were adequately remunerated. After the suspension of convertibility in 1797, the need for a means of payment encouraged the expansion of country banks notes. The return of convertibility in 1821 and the 1825 crisis forced the Bank of England to take responsibility for drawing up a ratio between reserves and liabilities (Clapham 1944, p. 124-125). This assumption of responsibility led to the so-called Palmer Rule, which guaranteed the convertibility of issued notes while it limited the credit that banks could provide (King 1936, pp. 38, 72-79).

The characteristics of the English banking system are not comparable with those of other European banking systems. The Bank of England, despite its private nature, acted as a pivot for the whole British banking system (Fetter 1965, pp.152-155, 258-259). The regulation of 1826 prohibited the creation of issuing banks fewer than sixty-five miles from London, thus favouring the expansion of Bank of England notes. This was not the case in France until the 1840s, or in Spain, where the Bank of Spain's banknotes did

\footnotetext{
(footnote continued)

and that the doctrine's true author is James Mill. A synthesis of this debate can be found in Gherity (1994).

5 The real bills doctrine was amply discussed early on by H. Thornton (1802) and D. Ricardo (associated with the Currency School), and was later rehabilitated by the Banking School.
} 
not have truly national circulation until the 1880s. The differences between the Bank of Spain and that of England had already been identified by Santillán, governor of the Bank of Spain in the mid-19 ${ }^{\text {th }}$ century. Among them, he pointed out that although the Bank of England performed the functions of a government cashier and was not paid for it, a margin of 23 days was reserved to use public revenues before paying them to the Treasury. On the other hand, the Bank of England received the deposits of an official nature, which in Spain was done by the Caja General de Depósitos. In addition, Bank of England notes were considered legal currency throughout the nation, which was not the case in Spain (Tedde de Lorca 2015, p. 160).

Banking in Spain originated almost exclusively as a handmaiden of the state, to satisfy its needs (Tortella Casares and García Ruiz 2013, p. 17). Banknotes had a very limited circulation until the mid-19 ${ }^{\text {th }}$ century, and Spanish banks did not habitually pay interest on term deposits or current accounts (Blasco-Martel 2016, pp. 89-94). Note convertibility was regulated late as well as loosely. Late, because it was not formally expressed until the proliferation of provincial banks; and loosely, because violating the norms bore no consequences. The Spanish credit market was tied to trade, and although by the mid- $19^{\text {th }}$ century industry was also a part of that, the countryside and its financial needs were not. At the end of the $18^{\text {th }}$ century, agrarian credit operated through a series of instruments adapted to a rural world characterised by the scarcity of capital (Peña-Mir 2016).

Spain's primary banking and issuing experience materialised in 1772 in the Bank of San Carlos, founded by King Carlos III, according to a project submitted by the French financier Francisco Cabarrús (Santillán 1865; Tedde de Lorca 1988). In 1829, the Bank of San Carlos was transformed into the Spanish Bank of San Fernando, and from 1844 onwards, there was a slow growth of banking institutions, with the appearance of the Bank of Isabel II and the Banks of Barcelona and Cádiz ${ }^{6}$. The 1856 laws that regulated banks of issue and credit societies, encouraged the opening of banks of issue all over the peninsula, and between 1856 and 1864, eighteen banks of issue were created (Sudrià i Triay and Blasco-Martel 2016). During this period, "the socalled 'metallist' school clearly held sway over the 'nominalist' school, which meant that the public, as well as the authorities, entertained the conviction that it was necessary and desirable to maintain a strong currency with a large specie content»(Martín-Aceña 2000, p. 114).

The spread of banknotes in monetary circulation, and the proliferation of banks that created money from deposits, raised a set of problems associated with the effect of monetary variables on the real economy. In a metallic

6 The Spanish Bank of San Fernando was renamed the Bank of Spain in 1856. In this article, these names are used indiscriminately. On the Bank of Isabel II, see Zumalacárregui (1952) and Tedde de Lorca (1995). On the Spanish Bank of San Fernando, see Santillán (1865) and Tedde de Lorca (1999). On the Bank of Barcelona, see Blasco-Martel and Sudrià (2010), and on the Bank of Cádiz, see Torrejón Chaves and Higueras Rodicio (2016). 
system, one of the turning points was in the relationship that existed between these financial innovations and the metallic reserves. The National Bank of Belgium expressed the Palmer Rule thus in their statutes: «The statutes only required that the NBB's metal stock had to represent at least one-third of its demand liabilities- the total value of banknotes in circulation plus the NBB's current account deposits» (Buyst and Maes 2008, p. 161). In France, in the middle of the $19^{\text {th }}$ century, there was also analysis of the stock of metal necessary to ensure the convertibility of banknotes. On the one hand, experience had shown it was sufficient to keep one-third in cash (d'Eichthal 1864 , p. 183); but on the other, it was clear that in boom times keeping a third of circulation as specie meant that resources were underutilised, while in times of crisis, this same amount was not considered sufficient (Legrand 1879, pp. 4-6). The Bank of Portugal, which maintained convertibility to gold between 1854 and 1891, incorporated the Palmer Rule for the first time (metallic reserve requirements of one-third notes and deposits) in 1888 (Reis 2007, p. 720).

Throughout the $19^{\text {th }}$ century bank deposits were also extended and so, therefore, was the ability of banks to create money through loans. The Bank of France, at the general meeting of shareholders in 1850, pointed out that current accounts formed part of the demandable liability, such as notes:

"Peut-être n'a-t-on pas assez généralement compris que les rapports entre l'Actif disponible et le Passif exigible ne variaient point dans la proportion de la hausse des Encaisses comparée au montant de la Circulation, car les Comptes-courants remboursables sur demande font partie du Passif exigible, aussi bien que les Billets en émission; or, ces Comptes-courants haussent toujours en même temps que les Encaisses ${ }^{7}$.

The Bank of France maintained very high reserves throughout the second half of the $19^{\text {th }}$ century. Thus, their metallic reserves regularly exceeded even the requirements of the Palmer Rule ${ }^{8}$.

The expansion of issuing banks in Europe occurred between the end of the $18^{\text {th }}$ and the first half of the $19^{\text {th }}$ centuries (Sudrià 2016, p. 45). Issuing banks obtained their resources by three means: the capital disbursed by stockholders, the notes issued by such institutions, and the funds deposited in current accounts. Issue of banknotes constituted the best introduction for a system of bank deposits, for it was easier to convince a person to accept a note, than to have them place their deposits in a banker's custody (Bagehot 1999). Notes were convertible at sight and to the bearer, which meant that they had to have very liquid guarantees. In the mid- $19^{\text {th }}$ century, French

\footnotetext{
${ }^{7}$ Assemblée Générale des Actionnaires de la Banque de France du 31 Janvier 1850.

8 Assemblée Générale des Actionnaires de la Banque de France (1850-1914).
} 
banker A. d'Eichthal suggested that an issuing bank's resources should follow this path: the capital entrusted by the public in exchange for the banknotes should be guaranteed, whether as metallic reserves available to its customers, or as state funds (he proposed that a share of public debt should represent half the notes); the capital that its customers placed in their current accounts should be applied to credit and discount operations (since its customers were mostly traders and merchants who used the bank as a safety deposit box); and finally, shared capital, which guaranteed its notes and its current account creditors, could be split between the two preceding categories, or placed in one, depending on circumstances (d'Eichthal 1864).

The aforementioned scheme was implicit in England's Bank Charter Act 1844, passed under the government of Robert Peel. The Act distinguished between notes that were guaranteed by government debt that actually represented gold, and banking operations that substituted bills of exchange and involved credit. The Bank of England's division into two departments the issuing department and the banking department - separated the monetary function of notes from their credit function. The issue of notes was fixed and guaranteed by public debt, so that any new notes had to be backed by gold, and only the Bank of England could issue new banknotes.

There was less agreement on the requirement for a guarantee on sight deposit than there was on notes. Robert Torrens had criticised the Bank of England in 1833 for permitting its issues to fluctuate without reference to its specie holdings, and he had also criticised the Palmer Rule for including deposits (Fetter 1965, p. 167). Other authors pointed out that the credit function would be realised only through bank deposits, because the condition of holding a portion of banknotes and deposits in cash could depress fiduciary circulation (Wolowski 1864, p. 399). Halfway through the $19^{\text {th }}$ century, the role of deposits and, therefore, the function that banks could perform as creators of money was still debated. Proof of this is found in the answer that Lord Overstone gave R. Torrens in an 1857 letter:

«Deposits are absolutely nothing -a mere right - a book debt - nothing more - they have neither intrinsic value, nor are they by custom or law the medium of universal exchange. Paper notes, or banknotes, are merely substitutes for the metallic money - resorted to on account of mechanical convenience and economy in use. Unless they are strictly the representatives of and substitutes for, the metallic coin - they are not true money - they are false and spurious pretenders» (O'Brien 1971, p. 714).

It is worth considering how all this controversy over banknotes and deposits was reflected in the operations of the Bank of England.

As can be seen in Figure 1 the amount of specie exceeded the requirements of the Palmer Rule in 1821. From 1825 until 1844, it is noted that, 
FIGURE 1

PALMER RULE IN THE BANK OF ENGLAND.

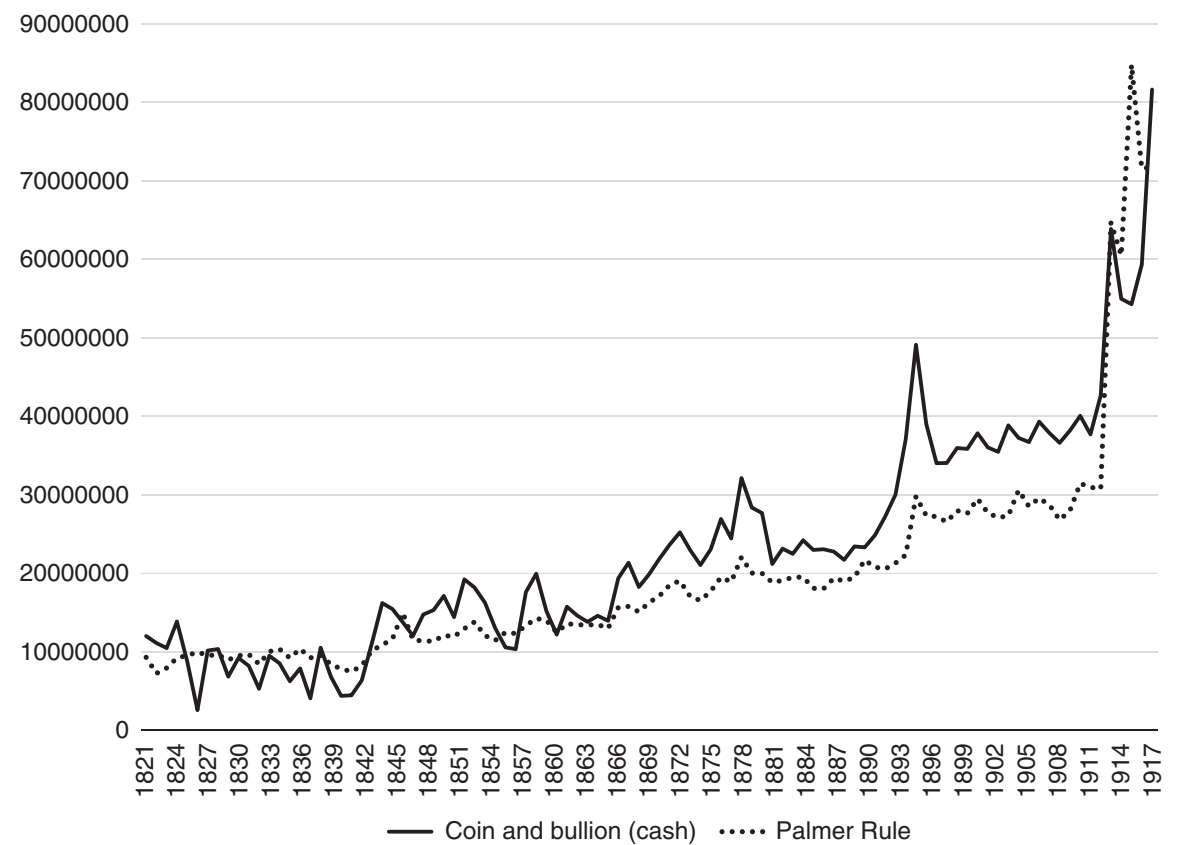

Source: The Bank of England's Annual Balance Sheet 1696-2014 (pounds): https://www. bankofengland.co.uk/statistics/research-datasets\#

despite the fluctuations, most of the time the liabilities of the Bank of England were not covered by the requirements of the Palmer Rule. The time periods during which the cash resources were below the Palmer Rule approximate the periods when the Bank suspended the 1844 law $(1847,1857$ and 1866; King 1936, p. 237). During the other periods, the Bank of England respected the Palmer Rule. This Figure does not correspond with the statement that «the Bank found that, partly because of a series of special circumstances, it was unable to operate the rule anyway» (O'Brien 2004, p. 183). Thus, the convertibility of notes is associated with compliance with this rule (even if such rule was not formally incorporated).

\section{REPUTATION AND ISSUING BANKS IN SPAIN}

Until the law of 1921, the banking laws in Spain had been primarily focussed on regulating emission. Despite this, the money supply grew faster 
than GDP: in 1850 M2 represented barely 15 per cent of GDP, whereas in 1920 it surpassed 30 per cent $^{9}$. Spanish issuing banks regulated their issue of banknotes using a twofold principle. Issuing was related partly to capital and partly to the amount of metallic reserves necessary to guarantee the convertibility of notes. Founded with state intervention and inextricably linked to government economic activity, the earliest banks - the Bank of San Carlos, and eventually, the Bank of San Fernando (which would become the Bank of Spain) - did not follow this system. From the end of the $18^{\text {th }}$ century, the Bank of San Carlos issued paper money through vales reales (royal bonds), which were "admissible at par and generated interest for all sorts of contributions, and were legal tender for all kinds of transactions, except for the payment of wages and retail trade» (White 1987, p. 511). Royal vouchers did not meet the requirements necessary to make them true banknotes; they were more a type of debt security put into circulation. The Bank of San Carlos, however, was also authorised to print notes, referred to as cédulas, and these were put into circulation for the first time in 1783, with a second issue taking place in 1797, although they both met with little success ${ }^{10}$.

The capacity to issue notes payable at sight and to the bearer, was granted to the Spanish Bank of San Fernando through the royal decree of 9 July 1829. This decree explicitly stated that the notes' bearers should be paid immediately and fully (without deductions). The law said nothing about limiting emission, leaving this matter to the discretion of the bank's governing board. Despite its relationship with the state, San Fernando was a private bank and the board was composed of businessmen and one state representative. San Fernando's banknotes were issued in Madrid, and although it did not open branches until after the 1856 law, its notes circulated in the provinces through its agent banks.

The Spanish Bank of San Fernando only admitted into its current accounts money or payables in Madrid. The funds available to current account holders were those that had already been made effective, since the bank did not advance cash, and dispensing payments or payment orders with non-existent funds was penalised (banks did not allow overdrafts). On the other hand, clients had to give ten days' notice if payable obligations were contracted with the bank. This 10-day notice period was a requirement unique to the Madrid bank, for provincial banks required a much briefer period, and it suggests that the Bank of San Fernando used the funds that it acquired through its current accounts for financial intermediation, and that this was part of the operative logic with which it was founded ${ }^{11}$. In fact, it

9 Data from Martín-Aceña and Pons Brías (2005) and Prados de la Escosura (2003).

10 See Tortella Casares (2008, p. 333), Fernández Marugan and Schwartz (1978, p. 423) and Tortella Casares (1997, p. 91-96). According to the essay written by Fernández Marugan and Schwartz (1978, pp.425-434), the paper money issued by the Bank of San Carlos did not adequately address the matter of convertibility.

11 Real Cédula 9 de Julio de 1829 and Reglamentos of 1832 (Bank of San Fernando). 
was considered that the crisis the Bank went through in 1847 was due to the fact that it had generated alarm and distrust among the population because the bank had used deposits ${ }^{12}$. During that time and until the mid- $19^{\text {th }}$ century, current accounts were considered a service provided by financial institutions to their customers, allowing them to collect or make payments more easily. However, the management of current accounts demanded a greater dedication from banking institutions than the management of banknotes. Voluntary deposits were free and Spanish coins, foreign currency in the shape of bullion, ingots, jewellery and government bonds, were all accepted. In general, the role of deposits in Spanish banking before 1874 lent itself to confusion, especially because term deposits were scarce (which makes sense, given that they did not attract interest ${ }^{13}$ ), and safety deposit boxes abounded, which appeared to make the banks' function that of mere custodian.

The regulatory system of Spanish provincial banks was based on those that governed the Bank of San Fernando. In 1844, the Bank of Isabel II in Madrid and the Bank of Barcelona were permitted to carry out credit operations in these cities. Legal limits were imposed on these banks' capacity to issue notes in relation to their capital. In the case of the Bank of Barcelona, it was required to keep a given percentage of metallic reserves to guarantee its notes. The Bank of Isabel II's maximum volume of emission of "cédulas al portador» (writs to the bearer) was limited to twice its paid-in capital (Statutes art. 6). However, shortly afterwards - in 1847 - this bank ceased to exist. The Bank of Barcelona could initially issue notes that equalled the total of its nominal capital, of which only one part was disbursed. The novelty introduced by this bank was that it included in its regulations a requirement for convertibility. Article 10 of its charter demanded that the bank keep a third of its issued notes in metallic reserves. Despite the fact that this was part of its official statutes, the directors of the Bank of Barcelona pointed out that "one of its obligations, which the Governing Board imposed on itself voluntarily, was to keep in its vault the third of its liabilities at sight ${ }^{14}$. This was the first time that the application of the Palmer Rule was mentioned in Spain, and it was indeed voluntary, for the bank's charter did not demand that the totality of the bank's liabilities be guaranteed.

12 See the brochure of Pablo Avecilla (1847, p. 15).

13 Martínez Méndez wrote: «The Bank (of Spain) always maintained a policy of nonremuneration of its liabilities in the form of deposits, for reasons that are not entirely clear, although presumably it was confident that its relative solvency was a powerful motive for attracting deposits» (2005, cap.15, p. 16). In a report about «Relations with the Bank of Spain» in 1927 (interviews with Bernis) it wrote that «no interest is paid by the Bank» in current accounts and cash deposits. See Bank of England Archive, file OV61/25.

${ }^{14}$ Minutes of the General Meeting of Shareholders of the Bank of Barcelona. 1 August 1847. 
The case of the Bank of Barcelona illustrates both the initial difficulties in establishing new monetary instruments, and the importance of building a reputation. In relation to the introduction of new financial instruments, it is known that, initially, the bank's notes were accepted without difficulty, while the opening of current accounts was slow and was promoted by the same directors who encouraged the members of board to extend them through the links of friendship (Blasco-Martel and Sudrià 2010, p. 99). In order to enhance its reputation, the Bank of Barcelona brought together the main businessmen of the city and built a network in which the greatest fortunes of the moment were linked, which in turn was fed by leading or participating in the main economic ventures (Badia-Miró et al. 2013). The Minutes of the Bank mention the importance of its reserves as a sign of the strength of the institution numerous times and the fact that, somehow, in the mental representation of those who had entrusted their funds to the bank, the image of the institution as a huge coffer full of metal persisted. In this sense, the words that the bank used to educate its clients in the bank's operations in relation to banknotes, the most delicate piece of banking operations, are very revealing. This is illustrated, for example, in the Minutes of the General Meeting of Shareholders on several occasions (especially at the beginning) in order to illustrate that «the only and recognised base to support the credit of the notes is the metallic currency». They also identify the Palmer Rule as their own: «Well-managed banks are considered in a normal state when they have the securities of the portfolio well secured and keep in cash one-third of their liabilities payable at sight, such as deposits, current accounts and bills issued. This is the type of the Bank of England and the other very accredited ones ${ }^{15}$. The directors of the Bank of Barcelona, in establishing compliance with the Palmer Rule, had the objective of stimulating trust in the institution and it is for this reason that they advertised it. In reality, the concepts of solvency and liquidity firmly overlapped at the time.

The 1847-1848 crises affected the Bank of San Fernando as well as the Bank of Barcelona (albeit for different reasons). This crisis forced the government to change the regulations, and it promulgated a royal decree (9 September 1848) that separated issuing from the rest of the institution's banking activities, just as the 1844 Peel Act had done with the Bank of England. The crisis also led to the passage of the 1849 and 1851 banking laws (Blasco-Martel 2016). The circulation of notes from the Bank of San Fernando was limited to twenty-five million pesetas (in July 1848 that volume had almost doubled), and Article 3 of the 1849 Banking Law stated that the Madrid Bank had reserve requirements of its notes by keeping a third of their

15 Minutes of the General Meeting of Shareholders of the Bank of Barcelona 12 July 1846, p. 2, and 2 February 1847, p. 2, respectively. These are not the only documents in which these aspects are referred to. See also: 2 February 1848, p. 3; 6 August 1848, p. 3 or the one of 5 August 1849, p. 3 referring to the «exuberance of metallic in strongbox». 
value in metallic reserves, and the rest in gilt-edged securities. However, the 1849 Law did not precisely reflect Britain's Palmer Rule, because the rest of the bank's current liabilities (current accounts and deposits) were not guaranteed.

Regulators at that time tried to make the Bank of San Fernando the country's single bank of issue. They failed in this endeavour and settled instead for regulating issues. In their attempt to alleviate the crisis that had affected the Bank of San Fernando, the effects of the laws of 1849 and 1851 actually went beyond the crisis, for they limited the volume of emission to banks' paid-in capital. The provincial banks of Barcelona and Cádiz had to reduce their issues accordingly, and this encouraged an increase in the number of banks' current accounts, which came to substitute notes in commercial operations. The regulation thus forcibly introduced the use of current accounts in banking business activity, in inverse proportion to the fall of notes in circulation. This situation would continue until 1856, when the Law of Banks of Issue liberalised the creation of banks of issue and credit societies.

The 1856 law stipulated that new provincial banks could accept deposits and issue notes, but the maximum volume of their emission could not exceed three times their paid-in capital. The banks of Barcelona and Cádiz were able to continue operating according to their existing bylaws. The wording of Article 20 of the 1856 law was very similar to that of Article 3 of the 1849 law, which stated that a bank's volume of emission should never exceed one-third of its metallic reserves. During the first half of the 1860s, the Bank of Spain faced a liquidity crisis, and for months at a time, its notes were either not convertible, or they were exchanged for gold due to the scarcity of silver in the market.

The first provincial banks of issue in Spain (Table 1) were born in response to traders' need for means of payment (Blasco-Martel 2004). Their activity encouraged the use of notes and the development of current accounts. Both instruments, although different, are dependent on the public's trust. In the case of notes, emission is controlled by the banker, while current accounts depend on the will of their customers to carry out their financial operations in the particular bank (Bagehot 1999, pp. 68-69). This is the difference between a deposit bank and a bank of issue. In the mid-19 ${ }^{\text {th }}$ century, Spanish provincial banks were a combination of both; they created notes and bank money through deposits. However, each bank behaved differently, depending on the relative proportion they held of each of these types of liability. In the Bank of Spain, for instance, current accounts during the period from 1852 to 1874 represented an average of 23 per cent of their total liabilities, whereas the average for provincial banks was 31 per cent.

Until 1856, notes and current accounts were used interchangeably and, for banks of issue, a fall in the circulation of notes was immediately translated into a rise in the volume of current accounts. After 1856, banks proliferated across the peninsula and significantly increased the circulation of 
TABLE 1

BANKS OF ISSUE IN SPAIN: 1844-1874

\begin{tabular}{|c|c|c|c|c|}
\hline Bank & $\begin{array}{l}\text { Year of } \\
\text { creation }\end{array}$ & Province & $\begin{array}{l}\text { Total assets by } \\
\text { capita } \\
\text { (Pesetas) }\end{array}$ & $\begin{array}{c}\text { Total assets by } \\
1.000 \text { pesetas } \\
\text { GDP }\end{array}$ \\
\hline Bank of Barcelona & 1844 & Barcelona & 34 & 61 \\
\hline Bank of Cádiz & 1846 & Cádiz & 54 & 84 \\
\hline Bank of Málaga & 1856 & Málaga & 27 & 46 \\
\hline Bank of Sevilla & $\begin{array}{c}1856- \\
1857^{*}\end{array}$ & Sevilla & 29 & 54 \\
\hline Bank of Spain & $1856^{* *}$ & & & \\
\hline Bank of Santander & 1857 & Santander & 31 & 102 \\
\hline Bank of Bilbao & 1857 & Vizcaya & 59 & 159 \\
\hline Bank of Zaragoza & 1857 & Zaragoza & 32 & 78 \\
\hline Bank of La Coruña & 1857 & La Coruña & 8 & 29 \\
\hline Bank of Valladolid & 1857 & Valladolid & 22 & 54 \\
\hline $\begin{array}{l}\text { Branch of Bank of } \\
\text { Spain in Alicante } y \\
\text { Valencia }\end{array}$ & 1858 & & & \\
\hline $\begin{array}{l}\text { Bank of Jerez de la } \\
\text { Frontera }\end{array}$ & 1860 & Cádiz & 54 & 84 \\
\hline Bank of San Sebastián & 1862 & Guipúzcoa & 20 & 63 \\
\hline Bank of Reus & $\begin{array}{c}1862- \\
1863^{*}\end{array}$ & Tarragona & 10 & 28 \\
\hline Bank of Burgos & 1863 & Burgos & 5 & 16 \\
\hline Bank of Pamplona & 1863 & Navarra & 7 & 17 \\
\hline Bank of Vitoria & 1864 & Álava & 14 & 45 \\
\hline Bank of Tarragona & 1864 & Tarragona & 10 & 28 \\
\hline Bank Balear & 1864 & Baleares & 7 & 19 \\
\hline Bank of Palencia & 1864 & Palencia & 6 & 15 \\
\hline Bank of Santiago & 1864 & La Coruña & 8 & 29 \\
\hline Bank of Oviedo & 1864 & Oviedo & 3 & 14 \\
\hline
\end{tabular}

Notes: *Authorisation and opening.

${ }^{* *}$ Formerly Spanish Bank of San Fernando.

Italics refer to Bank of Spain and branches.

Source: Gazeta de Madrid and Bernal Lloréns and Sánchez Ballesta (2016, p. 165).

banknotes in the economy. At the same time, the limitations imposed by state regulators so that the liabilities raised by issuing banks were remunerated, encouraged the formation of credit societies. The creation of the Caja General de Depósitos (a sort of National Savings Bank) in 1852 had launched 
the first interest-bearing current accounts (see Sánchez-Albornoz 1967, p. 6; Pérez de Armiñán 1977; Gonzalo-González 1981). In 1856, Credit Societies also started paying interest on their current accounts, which naturally led to an increase in customers, which in turn led to a decrease in current accounts in provincial banks. Eventually, some banks (such as the Bank of La Coruña) also paid interest on their customers' current accounts, but they were censured by the government. Other banks (such as that of Jerez) were not authorised by the state to do so, despite their expressed wishes (Bernal Lloréns and Sánchez Ballesta 2008, p. 76; Sudrià i Triay and Blasco-Martel 2016). After the 1866 crisis, the growth of current accounts across Spain would appear to suggest that the country had embarked on a process of modernising its use of financial instruments (see Martín-Aceña and Pons Brías 2005). However, not all provincial banks followed this trend. Their origins as well as their operations were heavily influenced by the region in which they had been established. Not all had the same capacity to raise current account enrolments. They did, however, share an extensive use of banknotes.

It has been pointed out that the regulatory system of Spain's issuing banks did not incorporate the Palmer Rule, but some banks did in fact apply it. It is important to note how the provincial banking sector and the Bank of Spain effectively used this rule. Figures 2 and 3 show the different behaviours of these banking institutions. In Figure 2, it can be seen that the Bank of Spain barely applied the Palmer Rule, for during almost the entire period indicated in the Figure, its metallic reserves were below the norm declared by the Bank of England to be an adequate reserve requirement for a bank. The explanation lies in the fact that the Spanish norm only guaranteed the convertibility of notes, and from that perspective, the institution's reserves only fell below its obligations during the years 1863 and 1864.

However, the Palmer Rule not only required that banks guarantee their notes, but guarantee the obligations to their customers as well - deposits and current accounts. Deposits were not particularly relevant in this period but starting in the mid-1860s they became more so. Whether we take into consideration term deposits (which can be regarded as some sort of loanable funds), or not, the evolution of the Palmer Rule that the Bank of Spain made, indicates that this institution used its customers' funds for financial intermediation. If this had not generated distrust among the public, it would not have been a problem. However, the Bank of Spain had difficulties in redeeming its notes on several occasions, as evidenced particularly in the 1860s. In addition to demand for not redeeming their notes (Pérez de Guzmán 1866), the bank also attracted criticism from the Congress of Deputies, where the government was required on different occasions to force the Bank of Spain to make cash payments of the notes ${ }^{16}$. The government, partly

16 See, for example, the Proceedings of Sessions of the Congress of Deputies of 22 May 1865, 5 February 1866 and 6 July 1866, among others. 
FIGURE 2

PALMER RULE IN THE BANK OF SPAIN (FORMERLY, THE SPANISH BANK OF SAN FERNANDO).

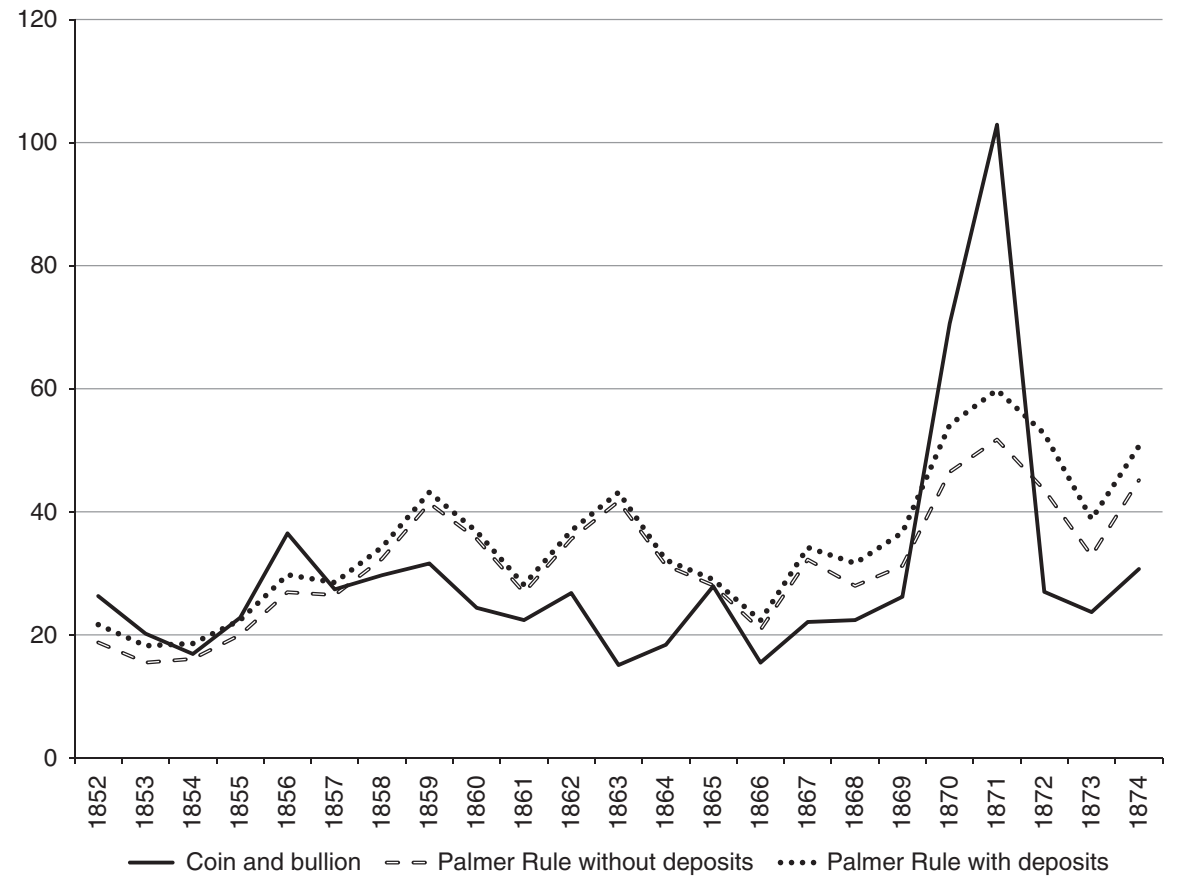

Source: Gaceta de Madrid (in millions of pesetas).

responsible for the bank's situation, had no way of enforcing the law. The behaviour of the Bank of Spain is explained by the fact that in its operations, its link with the Treasury was more important than its reputation among its customers. In fact, its clients were confident that the link established with national finances was, in addition to the reason for their existence, their safeguard. This was, in fact, the case. The Bank's business with the state maintained its dividends above virtually all issuing banks between 18561863 (Tedde de Lorca 2015, p. 133). However, these high dividends implied a greater risk that became evident when, in the early 1860s, it had difficulties redeeming its notes.

The behaviour of the provincial issuing banks during this period was different. The first issuing banks had to build a reputation. The Bank of Barcelona, one of the longest lived, understood that minimising reputational risk had a cost: keeping a portion of its loanable funds in reserve. That is why it assumed the Palmer Rule from the beginning of its operations. The Bank of Barcelona's example was followed by the other banks that appeared later. 
FIGURE 3

PALMER RULE IN BANKS OF ISSUE.

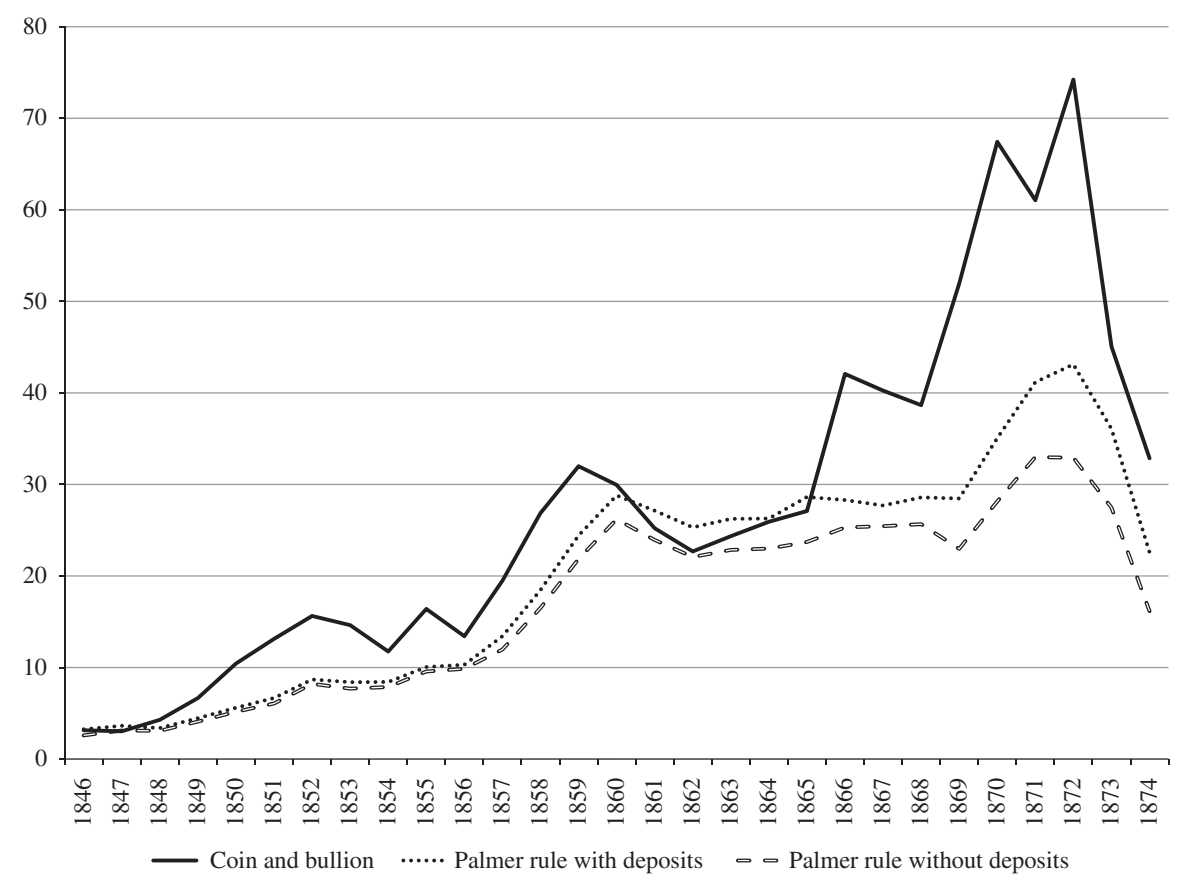

Source: Sudrià i Triay and Blasco-Martel (2016, appendix) (in millions of pesetas).

Aggregating the data of all provincial issuing banks (except the Bank of Spain), it can be seen in Figure 3 that the provincial banking sector behaved quite differently. First, deposits became significant after the law of 1856. This indicates that most provincial banks began attracting deposits intensively as soon as they were established. Before then, the banks of Cádiz and Barcelona had not raised significant funds using this financial instrument. This is important because the sector's compliance with the Palmer Rule is seen to have been more or less constant, except for the period of 1860-1866. However, if deposits are excluded - keeping in mind that their longer maturity explains why they were used in intermediation - the Palmer Rule was indeed enforced during the entire period in which multiple banks could issue notes.

Figure 3 also shows how, from 1860, there seems to have been a decision to dissociate deposits from the Palmer Rule. Until that time, there had been almost total alignment; however, from then on, banks appeared to keep a third of circulation and current accounts as cash in hand, but deposits were 
no longer guaranteed in this way. This might be related to the increase in the number of provincial banks, as well as their capacity to attract more deposits, but also to the appearance of the credit societies that competed with the issuing banks from 1856 onwards.

By the end of the 1860s, some of the banks that had been created thanks to the 1856 Law of Banks of Issue had disappeared, as well as several credit societies. The 1866 crisis, a projected law to build a national bank, and the absolutely liberalising regulation that was produced after the 1868 revolution, all characterised the final years of this decade (Sánchez-Albornoz 1963; Sánchez-Albornoz 1967; Sudrià and Navas 2007; Moro et al. 2015). The early 1870 s were marked by political instability, and the financial system continued operating under the previous laws until a royal decree, passed in 1874, brought the period of multiple banks of issue to an end (although further legal instruments had to be enacted in order to secure its application). This decree configured the monopoly of emission to favour the Bank of Spain, and it ended the stage of plurality of issuing institutions. During these years the Bank of Spain had many difficulties. The bankruptcy of Overend and Gurney was, in a way, providential to the institution which survived despite its performance, which was certainly weak in those years (Moro et al. 2015, pp. 188-192).

The end of the plurality of issuing was a response to the government's need to face the expenses derived from various military conflicts (the Carlist war and the first uprising for the independence of Cuba). Between 1870 and 1873 the Spanish government had leased the Almadén mines to the Rothschild house and, subsequently, it had sold the Riotinto mines to obtain liquidity. However, the situation was unsustainable, and the government was finding it increasingly difficult to obtain credit abroad and could not increase fiscal pressure domestically. The agreement of 1874 with the Bank of Spain was born of necessity; the government obtained an advance of 125 million pesetas from the Bank of Spain in exchange for the decree that made it the only issuer in the country.

\section{NOTES AND CONVERTIBILITY, 1874-1921}

The royal decree of 19 March 1874 finally awarded the Bank of Spain the monopoly of emissions that it had longed for. The simply stated norm emphasised two critical elements: the only banknotes that could circulate throughout the country were those issued by the Bank of Spain, and consequently the banknotes of issuing banks were illegal. According to Galvarriato, the 1874 law was the first to impose duty on the Bank of Spain's capital, thinking of its eventual emission. The previous laws had established the amount of capital purely by guesswork. According to this author, the circulation of notes in the 10-year period between 1874 and 1883 doubled 
thanks to the establishment of branches. In the next 5-year period (18841889), it doubled again (Galvarriato 1932, p. 102). The Bank of Spain had a dual task ahead: to give its banknotes credibility, which was not easy after the hits that these notes had taken during the previous decade; and to extend its notes across the entire peninsula. The Bank achieved this thanks to a network of franchises, and in cities that had banks of issue its notes were readily accepted ${ }^{17}$.

The volume of circulation took a giant leap with the 1884 unification of banknotes. The issue of 1 October 1886 was the first to be characterised by a note for all the Spanish provinces; in 1889, this emission was expanded (Tortella Casares 2008, p. 343). With the promulgation of the Commercial Code of 1885, the state "attempted to conciliate the liberal spirit of the time with a regulation that favoured banking intermediation» (Zunzunegui 1992, p. 126), but it failed. The new code allowed for the potential creation of future banks of emission and set out regulations for them, stating, however, that they could not be established until after the monopoly awarded to the Bank of Spain had expired ${ }^{18}$. The 1885 code also effectively incorporated reserve requirements vis-à-vis these future banks' responsibilities for customer funds. It stated that banks should «keep reserves in their vaults for a quarter, at least, of the total value of their metallic deposits and current accounts, as well as of circulating banknotes» (article 180). This was the first time that the Spanish regulatory system integrated the Palmer Rule, even though it was a hypothetical regulation, since it only affected banks that could be established once the present monopoly expired. The Bank of Spain was exempt from compliance with this rule ${ }^{19}$.

The period comprising the decades of the 1880s and 1890s is characterised, then, by an increase in the demand for notes. The Bank of Spain was not always capable of responding to this demand. During the early 1890s, the scarcity of banknotes made itself felt in many cities, among them, Barcelona, whose bank's Shareholders Meeting, in accordance with the regulation established by the aforementioned Commercial Code, voted in favour of requesting the government to award it a license to issue notes again $^{20}$. Finally, the Law of 14 July 1891 revealed just how closely the Bank of Spain and the Spanish Treasury collaborated with each other. This law doubled the bank's issuing capacity to 1,500 million pesetas, ending the

17 See Castañeda (2001, pp. 47, 65). Note that the Bank of Spain programmed all of its first franchises for provinces in which banks of issue had existed. See Sudrià i Triay and Blasco-Martel (2016).

18 See art. 123 and section 8 of the 1885 Commercial Code. In fact, the Bank of Spain never established reserve requirements for its clients' deposits or accounts. This surprised observers from the Bank of England. See Bank of England Archive, file OV61/25.

19 See art. 566, 1885 Commercial Code.

20 Minutes of Governing Board of the Banco de Barcelona, 28 July 1890. However, this was not pursued further, for the bank had to focus its efforts on addressing the effects of the 1890 international crisis. 
relationship between the bank's capital and its emissions, and tying emissions to metallic reserves (the bank was supposed to keep a third of circulation as metallic reserves, and at least half of those reserves had to be gold bullion). The law also extended the Bank's monopoly of issues until 1921, and allowed treasury debt to be counted as a current asset, thus laying the foundations for the monetisation of the deficit (Martín-Aceña et al. 2013).

How did current account enrolments and deposits evolve after the Bank of Spain was given a monopoly of emissions? Its monopoly on issuing notes had turned the Bank of Spain into a «national» bank (Castañeda 2001), and therefore its main objective was to provide the national economy with means of payment; however, the Bank of Spain still competed with the commercial banking sector ${ }^{21}$. Until 1900, it held nearly 60 per cent of Spain's overall savings. After that, the tables were turned, so that by 1910 it was the private banks that held 60 per cent of the country's savings and current accounts ${ }^{22}$.

The Law of 1874 had dedicated several articles to regulating the matter of banknote emission, clearly considering that this was the Bank of Spain's key function. If one is to judge the Bank's effectiveness in carrying out this mission, the constant complaints about the lack of money throughout the peninsula suggest that it was not entirely successful. It is very likely that the restrictions imposed on issues by tying them to the Bank's capital are what caused this shortage. This capital had been raised to 150 million pesetas in 1882, so that emissions represented ten times the Bank of Spain's capital. Thus, in just two decades, the Madrid Bank had increased tenfold the ratio maintained by banks of issue between their capital and their emissions. For its part, in those two decades the Bank of Spain had met two important goals: extending its branch network nationally, and extending the use of the note (Tortella Casares 1970). Moreover, the Bank of Spain's profits grew during the first 25 years of its emissions monopoly. In a law dated 14 July 1891, the Bank was required to hold one-third of the actual circulation, half in gold and half in silver. However, given the depreciation of silver and the fact that gold did not leave the Bank's coffers, convertibility was suspended de facto.

Figure 4 shows the evolution of the Bank of Spain's metallic reserves after it gained monopoly of issue. Until the early 1880 s the convertibility rule (expressed in the chart as the Palmer Rule) had been more than complied with. However, from then until the years immediately following the Villaverde reform, non-compliance with the convertibility rule was systematic.

It is a fact that by the end of the $19^{\text {th }}$ century, the Bank of Spain only converted notes into depreciated silver. Thus, some authors have pointed out

21 Competition between banks linked to governments and commercial banks in other countries is pointed out by Goodhart (1988, p. 9).

22 The data provided by Tedde de Lorca and Tortella Casares (1974) indicate that in 1875 commercial banks had 33 per cent of deposits and current accounts; in 1880, it was 34 per cent; in 1890 , only 22 per cent; while it rose to 36 per cent in 1900 and to 60 per cent in 1910 . 
FIGURE 4

BANK OF SPAIN. PALMER RULE 1874-1915.

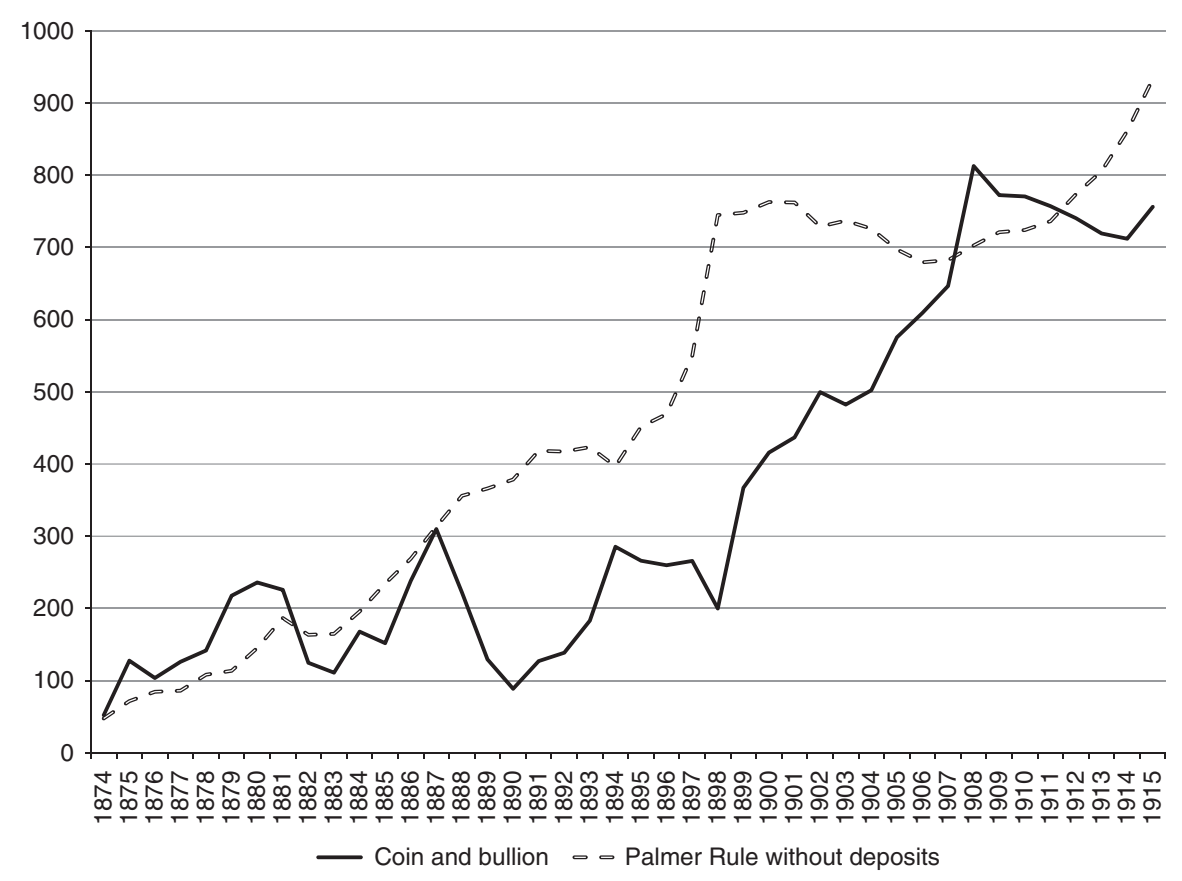

Source: Tedde de Lorca and Tortella Casares (1974) (in millions of pesetas).

that Spain had a de facto silver standard (Gay de Montellá 1953; Tortella Casares and García Ruiz 2013, p. 87). Others have questioned the very convertibility of the Spanish monetary system. Serrano argues that convertibility was the keystone of the gold standard system, and since convertibility in Spain was never fully assured, the country could not establish a commitment to gold (Serrano 2004, p. 21). Ródenas and Bru (2006, p. 559) indicate that, after the Figuerola Decree of 1868, Spain had a bimetallic standard and that convertibility was guaranteed by law. A more recent work by Martinez-Ruiz and Nogués-Marco $(2014$, pp. 19, 37) argues that from the 1880s, Spain had di jure bimetallism, but a de facto fiat system, and that the pretense of convertibility to gold came to an end in the 1890s. The credibility and reputation of central banks has changed over time. One of the factors that affected their reputation was the ability of these institutions to remain in the gold standard system (Bordo and Siklos 2016, p. 107). Spain never truly adopted the gold standard, and many historians argue that a major reason behind this was the difficulty encountered by the Bank of Spain in guaranteeing convertibility. 
The banking law of 1921, along with the 1931 law, regulated the Spanish financial system until the end of the Civil War. The 1921 law established a maximum level of emissions of 5,000 million pesetas, but it authorised the government to increase that level to 6,000 million if necessary. The law also stipulated that fiduciary circulation, up to 4,000 million pesetas, be backed by 40 per cent in gold, and from that amount the gold coverage was 60 per cent. Martín-Aceña argues that Minister Cambó preferred the "theory of convertibility» to the "theory of responsibility», and that meant not adopting any decisions regarding monetary policy. In fact, it was evident throughout this period that the Bank of Spain operated as a private bank with a preferential relationship with the state. Thanks to this its shareholders reaped great profits, despite the evident problem the bank's dual function represented for the country's financial system. The Bank of Spain could not assume a role as a monetary authority (Martín-Aceña 1984, p. 34) precisely because its primary responsibility was to its shareholders. Having failed to create a national bank that would address the common good in its monetary decisions, the Spanish government interfered with the financial institution by proceeding to enact monetary policies itself. Thus, the law of 1921 took some power away from the Bank of Spain, while allowing the limit of emissions to be:

«discretionally altered by the Government, acting solely in accordance with state interests, as had occurred in the past, and since the rule of metallic reserves was ineffective insofar as the country did not adopt the gold standard, one cannot say that the law identified effective criteria to regulate the money supply. Given that the real bills doctrine did not provide operative criteria either, one must acknowledge that the 1921 banking code simply ignored this key feature of monetary control» (Martín-Aceña 1984, p. 28).

\section{CONCLUSION}

Spanish banks, founded with close ties to the state and its needs, did not incorporate the convertibility of reserve requirements for their notes into their charters until provincial issuing banks were established. Even then, regulations only mandated that circulating notes be guaranteed by a metallic reserve equal to at least one-third of the total amount of such notes. This meant that customers' funds (current accounts and deposits) were not guaranteed by legislation or bank regulations. However, some provincial banks adopted stricter norms to regulate their own operations, such as the Palmer Rule; the first was the Bank of Barcelona, which voluntarily complied with the Palmer Rule to safeguard its operations adequately. The provincial banks of issue established after 1856, followed suit, and adopted at least part 
of the Palmer Rule, sometimes excluding term deposits from their guaranteed obligations. The Bank of Spain, with close ties to the state, barely complied with the Palmer Rule during the period when there were multiple banks of issue.

The differentiated behaviour of the provincial issuing banks was a response to their need to send a signal to their customers about their solvency. To build a reputation they adopted the Palmer Rule in its original version. Most provincial banks created in the period, with the notable exceptions of those of Valladolid and Sevilla, kept healthy balance sheets and were able to redeem their banknotes. It was the provincial banking sector that encouraged the extension and use of notes in the Spanish economy. It was also provincial banks that encouraged people to open current accounts and deposit their savings, because these institutions were physically located in customers' communities. Their administrators were known to the population, and usually enjoyed respectable reputations. The increase in paper money was therefore accomplished thanks to these financial institutions administering their cash vaults soundly, thus offering clients a sense of security. Certain institutions' commitments to large metallic reserves responded less to prudence than to the growth of their current account enrolments. These deposits made banks' coffers robust, which in turn favoured the introduction and extension of notes in economic exchanges. Thanks to the trust that provincial banks' notes generated, when the Bank of Spain was awarded the monopoly of issue in 1874, the single note issued by this privileged institution was almost universally accepted in those cities that had previously had a bank of issue.

Convertibility was never truly addressed in the origins of the banking institutions associated with the state. However, after the arrival of provincial banks of issue and the various crises associated with the Bank of Spain's convertibility, the latter opted for a bullionist model, in which notes were convertible according to a bimetallic standard. However, the bank's regulations allowed for this convertibility to be guaranteed with clients' deposits and current accounts, and not with shareholders' capital. Because of their proximity to their customers, or because they did not have the type of government backing the Bank of Spain enjoyed, provincial banks operated under an entirely different logic, even though there was no law preventing them from acting in the same way as the Bank of Spain. These banks had to build their reputation by sending signals to customers about their solvency and their ability to maintain the convertibility of their notes. When these banks were liquidated as institutions of issue in 1874, the convertibility of notes was left to an institution that was neither accustomed to, nor prepared to practise it. This allowed abnormal behaviour on the part of the Bank of Spain when it began to act alone. One of these anomalies is the rule, mentioned by the historiography but without empirical evidence, regarding the 
end of the convertibility of notes into gold, which took place «de facto» in the 1890s, although «de jure» the Bank continued to be obliged to respect it.

The goal of this work has been to analyse the causes and effects of the banking requirements and practices regarding metal reserves in the acceptance of banknotes in Spain. The provincial banks adopted the Palmer rule as an indicator of the soundness of their operations. The effects of this practice favoured the extension of banknotes in large parts of the country. The Bank of Spain did not need to disable so many funds in cash, given their relationship of mutual dependency with the Treasury. It did not need to discipline itself because its link with the Treasury offered it a high profitability at the cost of assuming important risks. The effect of this behaviour was manifested in the practical impossibility of entering the Gold Standard, due to the difficulty of the Bank in guaranteeing the convertibility of its notes.

\section{ACKNOWLEDGEMENTS}

Received 4 March 2018. Accepted 17 November 2018.

The author appreciates the ideas and comments provided by Pilar Nogués, Carles Sudrià, Rebeca Betancourt, Alejandra Irigoin, Yadira González de Lara and Enrique Jorge Sotelo. The author thanks Mercedes Bernal and Juan Pablo Sánchez for their generosity and Alison Keene for her help with the translation. This article also benefited from the financial assistance of the Science and Innovation Ministry's project HAR 2010-17482 and the SE-2011 project of the Generalitat de Catalunya. Earlier versions of this text were presented at the Congreso de la Asociación de Historia Contemporánea, Granada, 2012; CLADHE, Bariloche, 2013; Congreso de la Asociación Española de Historia Económica, Madrid, 2014; Encuentro de la Asociación Ibérica de Pensamiento Económico, Valencia 2015 and in the $1^{\text {st }}$ GLOCRED Workshop, Valencia 2017, as well as in two research stays, one in the Bank of France (2011) and another in Cañada Blanch (LSE) (2016), where I had access to relevant documents. Any mistakes or omissions are entirely the author's own.

\section{SOURCES AND OFFICIAL PUBLICATIONS}

Assemblée Générale des Actionnaires de la Banque de France 1850-1914: https:/gallica. bnf.fr/ark:/12148/cb327033321/date.

Gazeta de Madrid (1844-1921): https:/www.boe.es/buscar/gazeta.php.

Bank of England Archives. "Spain". File OV61/25.

General Meeting of Shareholders and Minutes of the Governing Board of the Bank of Barcelona. Archivo Nacional de Cataluña.

Proceedings of Sessions of the Congress of Deputies of Spain (1856-1868). http://www. congreso.es/est_sesiones/.

Commercial Code 1885. https://www.boe.es/datos/pdfs/BOE/1885/289/R00169-00648.pdf. 


\section{REFERENCES}

Allen, F.; Qian, J., and Qian, M. (2005): «Law, Finance, and Economic Growth in China». Journal of Financial Economics 77 (1), pp. 57-116.

Avecilla, P. (1847): Sociedades Anónimas. Madrid: Imprenta de la Publicidad.

Badia-Miró, M.; Blasco, Y.; Lozano, S., and Soler, R. (2013): «Redes sociales y negocios. la red de inversión del Banco de Barcelona en la economía catalana a mediados del siglo XIX». Investigaciones de historia económica 9 (3), pp. 143-154.

Bagenot, W. (1999 [1873]): Lombard Street: A Description of the Money Market, 1era edn. Nueva York: John Wiley \& Sons.

Bernal Lloréns, M., and Sánchez Ballesta, J. P. (2008): «Normalización contable de la banca española en los inicios de la industrialización». Revista de historia industrial 36, pp. 45-82.

Blasco-Martel, Y. (2004): «La aparición del Banco de Barcelona, 1844-1848». Quaderns d'història 11, pp. 177-196.

Blasco-Martel, Y. (2016): «Regulación bancaria y bancos provinciales en España», in C. Sudrià, and Y. Blasco-Martel (eds), La pluralidad de emisión en España, 1844-1874. Madrid: Fundación BBVA and Ed. Biblioteca Nueva, pp. 83-110.

Blasco-Martel, Y., and Sudrià, C. (2010): El Banco de Barcelona (1844-1874), historia de un banco emisor. Madrid: LID Editorial.

Bordo, M. D., and Siklos, P. L. (2016): «Central Bank Credibility. An Historical and Quantitative Exploration», in M. D. Bordo (ed.), Central Banks at a Crossroads. What Can We Learn from History?. New York: Cambridge University Press, pp. 62-144.

Buyst, E., and Maes, I. (2008): "Central Banking in Nineteenth-Century Belgium: Was the NBB a Lender of Last Resort?». Financial History Review 15 (2), pp. 153-173.

Camba-Mendez, G.; Carbo-Valverde, S., and Rodriguez-Palenzuela, D. (2014): «Financial Reputation, Market Interventions and Debt Issuance by Banks: A Truncated TwoPart Model Approach». Working Paper, European Central Bank, n. 1741.

CAstañeda, L. (2001): El Banco de España (1874-1900): la red de sucursales y los nuevos servicios financieros. Madrid: Banco de España.

Clapham, J. H. (1944): The Bank of England, a History. Cambridge, England: The University Press.

D’Eichthal, A. (1864): De la monnaie de papier et des banques d'émission. París: Guillaumin et Cie.

Diamond, D. (1983): «Reputation Adquisition in Debt Markets». Journal of Political Economy 97, pp. 828-861.

Fernández Marugan, F., and Schwartz, P. (1978): «El ensayo de José Alonso Ortiz», in A. Otazu (ed.), Dinero y crédito (siglos XVI al XIX). Madrid: Actas del primer Coloquio Internacional de Historia Económica, pp. 393-435.

Fetter, F. W. (1965): Development of British Monetary Orthodoxy:1797-1875. Cambridge, MA: Harvard University Press.

Flandreau, M. (1995): L'Or du monde: la France et la stabilité du Système monétaire international, 1848-1873. Paris: l'Harmattan.

Galvarriato, J. A. (1932): El Banco de España: constitución, historia, vicisitudes y principales episodios en el primer siglo de su existencia. Madrid: Banco de España.

Gay de Montellá, R. (1953): Tratado de la legislación bancaria española: legislación y jurisprudencia comercial, civil y fiscal y comentarios. Barcelona: Ed. Bosch.

GHerity, J. A. (1994): «The Evolution of Adam Smith's Theory of Banking». History of Political Economy 26 (3), pp. 423-441. 
Gonzalo-González, L. (1981): El tesoro público y la Caja General de Depósitos (18521868): un estudio sobre la deuda flotante en España a mediados del siglo XIX. Madrid: Instituto de Estudios Fiscales. Ministerio de Hacienda.

Goodhart, C. (1988): The Evolution of Central Banks. Cambridge, MA: The MIT Press.

Gorton, G. (1996): «Reputation Formation in Early Bank Note Markets». The Journal of Political Economy 104 (2), pp. 346-397.

Humphrey, T. M. (1982): «The Real Bills Doctrine». Economic Review (Sep), pp. 3-13.

KING, W. T. C. (1972 [1936]): History of the London Discount Market. London: Frank Cass.

Knodell, J. (2010): «The Role of Private Bankers in the US Payments System, 18351865». Financial History Review 17 (2), pp. 239-262.

LEGRAND, A. (1879): Le Billet de banque fiduciaire, sa fabrication, son mode d'émission, son rôle, sa suppression. París: Impr. de la Société anonyme de publications périodiques.

Martín-Aceña, P. (1984): La Política monetaria en España, 1919-1935. Madrid: Instituto de Estudios Fiscales.

Martín-Aceña, P. (2000): «The Spanish Monetary Experience», in P. Martín-Aceña, and J. Reis (eds), Monetary Standards in the Periphery: Paper, Silver and Gold, 1854-1933. London: Macmillan Press Ltd, pp. 112-151.

Martín-Aceña, P. (2017): The Banco de España, 1782-2017 The History of a Central Bank. Madrid: Banco de España.

Martín-Aceña, P.; Martínez-Ruíz, E., and Nogués-Marco, P. (2013): «The Bank of Spain: a National Financial Insitution». Journal of European Economic History 42 (1), pp. 11-46.

Martín-Aceña, P., and Pons Brías, M. A. (2005): «Sistema monetario y financiero», in A. Carreras, and X. Tafunell (eds), Estadísticas históricas de España: siglo XIX-XX. Madrid: Fundación BBVA, pp. 645-706.

Martínez Méndez, P. (2005): Tesoro y Banco de España (1900-1936). Madrid: Banco de España. (unpublished manuscript).

Martinez-Ruiz, E., and Nogués-Marco, P. (2014): Crisis cambiarias y políticas de intervención en España, 1880-1975. Madrid: Banco de España.

Martínez-Ruíz, E., and Nogués-Marco, P. (2018): «The Political Economy of Exchange Rate Stability During the Gold Standard. Spain 1874-1914». Discussion paper series HIAS-E-75, Hitotsubashi Institute for Advanced Study, Hitotsubashi University.

Moro, A.; NuÑo, G., and Tedde, P. (2015): «A Twin Crisis With Multiple Banks of Issue: Spain in the 1860s». European Review of Economic History 19 (2), pp. 171-194.

O'Brien, D. P. (1971): The Correspondence of Lord Overstone (vol. 2). Cambridge: Cambridge University Press.

O’Brien, D. P. (2004): Classical Economists Revisited. Princeton, NJ: Princeton University Press.

Pastor Rodríguez, L. M. (1850): «Filosofia del credito: deducida de la historia de las naciones más importantes de Europa; con un apéndice en que se aplica la teoría al estado actual de España y al arreglo de su deuda». Madrid. Impr. de D.W. Ayguals de Izco.

PeÑA-MiR, J. L. (2016): «Financiación y especialización productiva: el mercado de crédito malagueño a finales del sigloXVIII». Investigaciones de Historia Económica Economic History Research 12, pp. 113-143.

Pérez de Armiñán, G. (1977): Legislación bancaria española. Madrid: Banco de España.

Pérez de Guzmán, E. (1866): Cambio de billetes del Banco de España: consideraciones del Marqués de Santa Marta con motivo del informe emitido sobre esta cuestión. Madrid: Imprenta y Estereotipia de M. Rivadeneyra. 
Perlman, M. (1989): «Adam Smith and the Paternity of the Real Bills Doctrine». History of Political Economy 21 (1), pp. 77-90.

Poitras, G. (1998): «Robert Torrens and the Evolution of the Real Bills Doctrine». Journal of the History of Economic Thought 20 (4), pp. 479-498.

Prados de la Escosura, L. (2003): El progreso económico de España 1850-2000. Bilbao: Fundación BBVA.

ReIs, J. (2007): «An “Art”, Not a "Science"? Central Bank Management in Portugal under the Gold Standard, 1863-87». Economic History Review 60 (4), pp. 712-741.

RódenAS, C., and BRu, S. (2006): "La converbibilidad de la peseta en el siglo XIX». Revista de Historia Económica/Journal of Iberian and Latin American Economic History 3, pp. 555-578.

Ruiz, B.; Esteban, Á., and GutiérRez, S. (2014): «Determinants of Reputation of Leading Spanish Financial Institutions among their Customers in a Context of Economic Crisis». Business Research Quarterly 17 (4), pp. 259-278.

Sánchez-Albornoz, N. (1963): "La crisis de 1866 en Barcelona:(notas para su estudio)», in Homenaje a Ramón Carande (vol. 2). Madrid: Sociedad de Estudios y Publicaciones, pp. 421-436.

Sánchez-Albornoz, N. (1967): «La crisis de 1866 en Madrid: la Caja de Depósitos, las sociedades de crédito y la Bolsa». Moneda y crédito 100, pp. 3-40.

Santillán, R. (1865): Memoria histórica sobre los Bancos Nacionales de San Carlos, Español de San Fernando, Isabel II, Nuevo Banco de San Fernando y de España. Madrid: Banco de España.

SERrano, J. M. (2004): El oro en la Restauración. Discurso de Recepción en la Real Academia de Ciencias Morales y Políticas. Madrid: Real Academia de Ciencias Morales y Políticas.

SudRià, C. (2016): «La experiencia de la pluralidad de emisión en Europa», in C. Sudrià, and Y. Blasco-Martel (eds), La pluralidad de emisión en España, 1844-1874. Madrid: Fundación BBVA y Ed. Biblioteca Nueva, pp. 41-80.

SudRià, C., and NAVAS, M. (2007): «La crisi financiera de 1866 a Catalunya: una revisió». Recerques 55, pp. 35-72.

Sudrià i Triay, C., and Blasco-Martel, Y. (eds) (2016): La pluralidad de emisión en España, 1844-1874. Madrid: Fundación BBVA and Ed. Biblioteca Nueva.

Tedde de Lorca, P. (1988): El Banco de San Carlos (1782-1829). Madrid: Banco de España/Alianza Editorial.

Tedde de Lorca, P. (1999): El Banco de San Fernando. Madrid: Alianza Editorial.

Tedde de Lorca, P. (2015): El Banco de España y el Estado liberal (1847-1874). Madrid: Banco de España y Gadir Editorial.

Tedde de Lorca, P., and Tortella Casares, G. (1974): «Censo y balances normalizados de los bancos privados españoles, 1874-1914», in G. Tortella Casares (ed.), La banca española en la Restauración. Madrid: Servicio de Estudios del Banco de España, pp. 211-490.

Thornton, H. ([1802] (2000)): Crédito papel: una investigación sobre la naturaleza y los efectos del crédito papel de Gran Bretaña. Madrid: Pirámide.

Torrejón Chaves, J., and Higueras Rodicio, R. (2016): "Los bancos de Cádiz (18461874)", in C. Sudrià, and Y. Blasco-Martel (eds), La pluralidad de emisión en España, 1844-1874. Madrid: Fundación BBVA and Ed. Biblioteca Nueva, pp. 244-269.

Tortella Casares, G. (1970): «El Banco de España entre 1829-1929: la formación de un banco central», in F. Ruiz Martín (ed.), El Banco de España. Una historia económica. Madrid: Banco de España, pp. 263-315. 
Tortella Casares, G., and García Ruiz, J. L. (2013): Spanish Money and Banking: A History. Basingstoke: Palgrave Macmillan.

Tortella Casares, T. (1997): Los primeros billetes españoles: las "cédulas" del Banco de San Carlos (1782-1829). Madrid: Banco de España.

Tortella Casares, T. (2008): «El billete español en la Edad Contemporánea: Mucho más que un medio de pago». VII Jornadas Científicas sobre Documentación Contemporánea (1868-2008), Madrid. pp. 331-368.

White, E. N. (1987): «¿Fueron inflacionarias las finanzas estatales en el siglo XVIII? Una nueva interpretación de los vales reales». Revista de Historia Económica 5 (3), pp. 509-526.

Wolowski, L. (1864): La question des banques. Paris: Guillaumin.

ZumalacárRegui, L. (1952): El Banco de Isabel II y la crisis de la banca de emisión española de 1847. Madrid: Gráficas Reunidas.

Zunzunegui, F. (1992): Ordenación bancaria. Madrid: Espasa-Calpe. 